\title{
The apron challenge: embodied and creative learning online and at a distance.
}

\author{
Tom Burns \\ London Metropolitan University \\ John Desire \\ London Metropolitan University \\ Janet Gordon \\ London Metropolitan University \\ Sandra Sinfield \\ London Metropolitan University
}

Keywords: embodied learning; creative classrooms; reflective practice; cohort identity; online learning; Covid-19.

\section{The challenge}

The playful experimenters full of curiosity who are not afraid to break the rules, invent new ones and explore new territories, are stepping into the limelight (Nerantzi, 2019).

Facilitating Student Learning (FSL) is the first module in our Postgraduate Certificate in Learning and Teaching in Higher Education (PGCert). Typically, six of the seven sessions are delivered face-to-face (F2F) and one online. It is designed to be a highly creative, ludic module (Sinfield et al., 2019) that 'de-schools' (Illich, 1970) and 'unschools' (Holt 1977; 1981) participants, helping to disrupt normative expectations of education, teaching, learning and assessment. With the recent Covid-19 lockdown policies, rather than hope for the return of F2F teaching, we decided to deliver the module totally online. Given that most of our students are staff new to UK university teaching, and unexpectedly delivering their first teaching completely online, we wanted our module to stand beside them, to help and encourage. We wanted to design, and for participants to experience, that learning itself is not just a cognitive process, but is experiential, emotional, social, interpersonal and embodied (Wenger-Trayner, 2014; Clughen, 2017). 
FSL itself is a course that is informed and shaped by Learning Development values (ALDinHE, 2021). Our philosophy is that to facilitate learning you have to work in partnership with students, and they in partnership with each other, to make transparent the (contested) forms and processes of academia and to rehearse empowering strategies that promote higher learning (Angelo, 1993). In FSL, staff experience creative processes that enable them to participate actively, powerfully and with agency in their own learning. In this way, we argue that our module is designed to 'de-colonise' pedagogy by shaking up notions of what university is and what it can become. The challenge that we were attempting to address in this online iteration of the module was how, virtually and in creative and dialogic ways, we could build a cohort ready to experiment playfully (Winnicott, 1971) with their own teaching, learning and assessment approaches. We wanted our staff-as-students to 'be with' (Nancy, 2000) each other, reinforcing the embodied experience, and we wanted to start the process before our participants began the module itself.

\section{The response}

We undertook a complete overhaul and re-design of the module, opening ourselves up to different ways of conceptualising the curriculum. Whereas previously each F2F session would harness play, collage making, drawing, free writing and other forms of emergent and playful practice, we had to work out how much of this we would try to recreate in 'class' via our virtual learning environment and how much might now need to happen in the student's home, alone. We needed to capture that emergence, that potentiality, online.

But before that, we wrestled with how to build bonding and belonging (Leathwood and O'Connell, 2003) and an embodied sense of the FSL learning process itself, even before the students arrived. Previously, our colleague, Simone Maier, had developed a 'jeans to study apron' activity, in which the making process allowed her to think about preparing herself for study. We decided to adopt that as an induction challenge for our students, with alternatives that would allow everybody to participate and succeed, so our students could make a study space, object or the apron: 


\section{Make a study apron (see example video):}

Find a large old pair of jeans or similar - transform the jeans into a study apron something that makes you feel like a proper student. Share the process/product in the class Padlet.

Whichever challenge was accepted, we asked for a picture and a few words posted to the class Padlet, and asked participants to read and respond to posts from classmates before the first class.

We evaluated this activity by reading the participants' weekly reflective blogs and by discussing it directly in class. We also reflected on the activity ourselves, exploring the class Padlet to see how people had responded, noticing the creativity and variety of the ways that they had engaged with the challenge. Some wrote poetry instead of making an apron; others made more than one sort of study space and shared all of them.

Ironically the person who actually made the study apron was the most overtly sceptical of the task itself: "Really? How is this going to help me with my teaching skills?" She was the one who then plunged in with energy, excitement and frustration. This person had made an apron and shared it with the class on the Padlet for this activity along with a link to her reflective blogpost on the whole experience. She was angry with herself; she had rushed in too quickly, had made numerous mistakes; she had produced a terrible apron and was a terrible person. This is the value of embodied practice; it unleashes insights that theory alone could not reveal. Discussing the passion experienced by this participant not only reassured her that her participation had been valuable and powerful, it also provided a useful talking/learning point for the group.

\section{Recommendations}

This paper reflects on how we set participants up to positively experience a learningdevelopment-inspired staff PGCert module. Our challenge was to lead them into a creative, embodied and playful experience, even though they would be studying online and at a distance. The 'apron challenge' was not just a throwaway one-off icebreaker, but a 
synecdoche for the module itself: playful, collaborative, supportive, embodied and online. The processes provoked movement from individual cognitive, creative, haptic, multimodal experiences to a collective, reflective and dialogic experience. By 'being with' in creative and embodied ways, students started to get to know each other even before the first virtual class, and that continued into virtual engagement and reflection in and out of class. The class was challenging and disruptive of preconceived ideas of academic practices, but in exploratory, discursive and emergent ways. The module stood with and beside the students, and they with each other.

We would encourage others to design similar creative, collaborative and embodied activities in their own online spaces. Encourage students to get up and move around. Set up a scavenger hunt. Ask participants to find an object that represents their thoughts on the topic. Require them to 'make, do, share, discuss' before, during and after class. Being creative in the online learning and teaching space can be as embodied and powerful as in face-to-face classes if we reimagine our blended practice not just as an emergency response to a pandemic, but as collaborative dancing on the edge.

\section{References}

ALDinHE (2021) Association of Learning Development in Higher Education. Available at: https://aldinhe.ac.uk/ (Accessed: 6 May 2021).

Angelo, T.A. (1993) 'A “Teacher's dozen”: fourteen general, research-based principles for improving higher learning in our classrooms, AAHE Bulletin, 45(8), pp.3-7. Available at: https://www.researchgate.net/publication/237489105 A Teacher's DozenFourteen General Research-Based Principles for Improving Higher Learning (Accessed: 29 July 2021)

Clughen, L. (2017) 'Editorial', in Clughen, L. and Willis, J. (eds) Creative Academic Magazine: role of the body in creative processes \& practices. Available at: https://www.creativeacademic.uk/uploads/1/3/5/4/13542890/cam8.pdf (Last downloaded: 12th May 2021). 
Holt, J. (1977) Growing without schooling. Available at:

https://www.johnholtgws.com/growing-without-schooling-issue-archive/ (Accessed: 23 June 2021).

Holt, J. (1981) Teach your own: A hopeful path for education. New York: Delacorte Press/Seymour Lawrence.

Illich, I. (1970) De-schooling society. New York: Harper and Row.

Leathwood, C. and O'Connell, P., (2003) "It's a struggle": the construction of the "new student" in higher education', Journal of Education Policy, 18(6), pp.597-615. Available at: https://doi.org/10.1080/0268093032000145863 (Accessed 29 July 2021).

Nancy, J. (2000) Being Singular Plural. Stanford, CA: Stanford University Press.

Nerantzi, C. (2019) 'The playground model revisited: a proposition for playfulness to boost creativity in academic development' in James, A. and Nerantzi, C. (eds) The power of play in higher education: creativity in tertiary learning. Cham: Springer International Publishing AG.

Sinfield, S., Burns, T. and Abegglen, S. (2019) 'Becoming playful: the power of a ludic module' in James, A. and Nerantzi, C. (eds) The power of play in higher education: creativity in tertiary learning. Cham: Springer International Publishing AG.

Wenger-Trayner, E. (2014) 'Learning in landscapes of practice: recent developments in social learning theory', ALDinHE Annual Conference 2014: Learning development spaces and places. University of Huddersfield, April 2014.

Winnicott, D.W. (1971) Playing and reality. London: Tavistock. 


\section{Author details}

Tom Burns, John Desire, Janet Gordon and Sandra Sinfield are senior lecturers in the Centre for Professional and Educational Development at London Met, with a special focus on teaching, learning and assessment practices - face-to-face and online - that ignite student curiosity, harness creativity and develop power and voice. 